\section{Quantifying the Effects of Chelated Calcium and Salicylic Acid on the Postharvest Quality of Poinsettia Cuttings}

\author{
Uttara C. Samarakoon ${ }^{1}$ and James E. Faust ${ }^{2}$
}

ADDITIONAL INDEX WORDs. Euphorbia pulcherrima, leaf mechanical strength, nutrient analysis, texture analyzer

SUMMARY. Vegetatively propagated unrooted cuttings typically are grown in equatorial locations and shipped via airfreight to propagators located in temperate climates. Cutting quality, defined as the resistance to external forces, such as physical damage and pathogen infection, impacts postharvest durability during shipping and propagation. During our previous studies, foliar application of calcium $(\mathrm{Ca})$ in the form of $\mathrm{Ca}$ chloride was effective at increasing leaf mechanical strength of poinsettia (Euphorbia pulcherrima) and zonal geranium (Pelargonium $\times$ hortorum). Calcium chloride applied at $\geq 800 \mathrm{mg} \cdot \mathrm{L}^{-1} \mathrm{Ca}$ caused phytotoxicity symptoms in poinsettia; therefore, in the current work, we investigated the use of chelated Ca by providing Ca at 40,80 , or $160 \mathrm{mg} \cdot \mathrm{L}^{-1}$ and salicylic acid (SA) at 150 or $300 \mathrm{mg} \cdot \mathrm{L}^{-1}$ to increase the mechanical strength of poinsettia leaves. Mechanical strength of leaves was assessed using a force-displacement graph generated from a texture analyzer using a ball probe to penetrate a unit area of a clamped leaf. The peak force to fracture the leaf and work-of-penetration, defined as the area under the force-displacement curve, were used as indicators of mechanical strength. Calcium concentration in the leaves increased by $27 \%$ with increased application of Ca from 0 to $160 \mathrm{mg} \cdot \mathrm{L}^{-1}$. Peak force was $26 \%$ greater in treatments with $\mathrm{Ca}$ at 80 or $160 \mathrm{mg} \cdot \mathrm{L}^{-1}$ compared with the untreated control. Work-of-penetration was $24 \%$ and $29 \%$ greater for treatments with $\mathrm{Ca}$ at 80 and $160 \mathrm{mg} \cdot \mathrm{L}^{-1}$, respectively, compared with the control. Foliar application of SA did not affect leaf mechanical strength. Chelated $\mathrm{Ca}$ applied at $160 \mathrm{mg} \cdot \mathrm{L}^{-1} \mathrm{Ca}$ caused visual phytotoxicity symptoms; thus, applications of $80 \mathrm{mg} \cdot \mathrm{L}^{-1} \mathrm{Ca}$ are recommended to improve resistance to physical damage for poinsettia leaves.

$\mathrm{V}$ egetatively propagated herbaceous ornamental species typically are started from shoot tip cuttings harvested from stock plants, densely packed into plastic bags and cardboard boxes, and transported via airfreight to propagators. The time from harvesting the cuttings to

Received for publication 2 Oct. 2018. Accepted for publication 16 Nov. 2018.

Published online 4 February 2019.

Department of Plant and Environmental Sciences, Clemson University, E143 Poole Agriculture Center, Clemson, SC 29634

Technical Contribution No. 6721. Clemson University Experiment Station. We thank the American Floral Endowment and the U.S. Department of Agriculture United States Department of Agriculture (USDA-ARS) Floriculture and Nursery Research Initiative for their financial support for this project, Scott Whiteside (Clemson University Experiment Station) for sharing instrumentation, Douglas Sturtz (USDAARS) for nutrient analysis, and Alexandra Carver for technical assistance.

${ }^{1}$ Current address: The Ohio State University Agricultural Technical Institute, 1328 Dover Road, Wooster, OH 44691.

${ }^{2}$ Corresponding author. E-mail: jfaust@clemson.edu.

This is an open access article distributed under the CC BY-NC-ND license (https://creativecommons.org/ licenses/by-nc-nd/4.0/).

https://doi.org/10.21273/HORTTECH04200-18 delivery at the propagation greenhouse is typically 48 to $72 \mathrm{~h}$. Delays during shipping or poor cold-chain management can result in leaf chlorosis, leaf abscission, delayed root initiation, and fungal infections. A goal of the stock plant grower is to produce cuttings that resist these physiological and pathogenic problems. Growers empirically evaluate the cutting quality that impacts postharvest durability during shipping and propagation and refer to the desired characteristics as "toning," which is defined as the change in leaf texture required to provide resistance to external forces such as physical damage or pathogen infection. During our previous studies (Samarakoon et al., 2017), techniques were developed to quantify the mechanical strength of leaves with the use of instruments that assess textural properties. Peak force to puncture a leaf (strength) and work-of-penetration (toughness), given by the positive area of the force displacement curve, are two parameters derived from mechanical strength tests that provide an indication of the mechanical resistance of leaves to external forces.

The effect of preharvest foliar $\mathrm{Ca}$ chloride $\left(\mathrm{CaCl}_{2}\right)$ applications on mechanical strength were quantified with the use of zonal geranium and poinsettia as model species (Samarakoon et al., 2017). Use of Ca at $400 \mathrm{mg} \cdot \mathrm{L}^{-1}$ in the form of $\mathrm{CaCl}_{2}$ as a preharvest treatment was effective at increasing the mechanical strength of poinsettia; however, concentrations $\geq 800 \mathrm{mg} \cdot \mathrm{L}^{-1}$ caused phytotoxicity symptoms. Chelated $\mathrm{Ca}$ that contains ethylenediaminetetraacetate (EDTA) can improve Ca absorption at lower $\mathrm{Ca}$ concentrations with root uptake (Nelson and Niedziela, 1998), as well as with foliar applications (Tang et al., 2007). The commercial crop recommendation of Ca-EDTA foliar application is 20 to $40 \mathrm{mg} \cdot \mathrm{L}^{-1} \mathrm{Ca}$ (W.R. Argo, personal communication); however, Ca-EDTA was unable to overcome $\mathrm{Ca}$ deficiencies when applied as a foliar application (Alarcón et al., 1998). The first objective of the current research was to quantify the effect of preharvest foliar application of Ca-EDTA on the postharvest leaf mechanical strength of poinsettia cuttings.

SA mediates plant defense responses against biotic and abiotic stresses (Hayat et al., 2010; Rivas-San

\begin{tabular}{llll}
\hline $\begin{array}{l}\text { Units } \\
\text { To convert U.S. to SI, } \\
\text { multiply by }\end{array}$ & U.S. unit & SI unit & $\begin{array}{l}\text { To convert SI to U.S., } \\
\text { multiply by }\end{array}$ \\
\hline 29.5735 & $\mathrm{fl} \mathrm{oz}$ & $\mathrm{mL}$ & 0.0338 \\
318.3268 & $\mathrm{fl} \mathrm{oz} / \mathrm{ft}^{2}$ & $\mathrm{~mL} \cdot \mathrm{m}^{-2}$ & 0.0031 \\
0.0929 & $\mathrm{ft}^{2}$ & $\mathrm{~m}^{2}$ & 10.7639 \\
3.7854 & gal & $\mathrm{L}$ & 0.2642 \\
2.54 & inch $(\mathrm{es})$ & $\mathrm{cm}$ & 0.3937 \\
25.4 & inch $(\mathrm{es})$ & $\mathrm{mm}$ & 0.0394 \\
645.1600 & inch & $\mathrm{mm}$ & 0.0016 \\
28.3495 & $\mathrm{Oz}$ & $\mathrm{g}$ & 0.0353 \\
720.0779 & $\mathrm{Oz}-\mathrm{inch}$ & $\mathrm{g} \cdot \mathrm{mm}$ & 0.0014 \\
1 & $\mathrm{ppm}$ & $\mathrm{mg} \cdot \mathrm{kg}^{-1}$ & 1 \\
1 & $\mathrm{ppm}$ & $\mathrm{mg} \cdot \mathrm{L}^{-1}$ & 1 \\
0.001 & $\mathrm{ppm}$ & $\mathrm{mL} \cdot \mathrm{L}^{-1}$ & 1000 \\
$\left({ }^{\circ} \mathrm{F}-32\right) \div 1.8$ & ${ }^{\circ} \mathrm{F}$ & ${ }^{\circ} \mathrm{C}$ & $\left({ }^{\circ} \mathrm{C} \times 1.8\right)+32$ \\
& & & \\
\hline
\end{tabular}


Vicente and Plasencia, 2011) and increases the postharvest life of cut roses (Rosa $\times$ bybrida) when applied as a preand postharvest application (Alaey et al., 2011). The effect of SA in increasing leaf mechanical strength has not been reported; however, fruit firmness increased when SA was added to the nutrient solution supplied to strawberries [Fragaria ×ananassa (Shafiee et al., 2010)] and when SA was applied as a foliar spray to grapes [Vitis vinifera (Champa et al., 2014)]. Therefore, the second objective of the current research was to quantify the effect of preharvest SA application on postharvest leaf mechanical strength of poinsettia cuttings.

\section{Materials and methods}

STOCK PLANT MANAgEMENT. Poinsettia 'Prestige Red' rooted cuttings were transplanted into $2.8-\mathrm{L}$ containers, one plant per container. Six weeks following planting, the shoot tips were pinched (about $1 \mathrm{~cm}$ below the shoot apex) to leave six nodes on the remaining stem, and treatment applications started 2 weeks later. The plants were grown in a glass greenhouse in which the heating and ventilation set points during day and night were 27 and $22^{\circ} \mathrm{C}$, respectively. Plants were shaded with retractable curtains $[55 \%$ photosynthetic photon flux (PPF) reduction] when $P P F$ measured outside the greenhouse exceeded $968 \mu \mathrm{mol} \cdot \mathrm{m}^{-2} \cdot \mathrm{s}^{-1}$. Plants were grown under long days provided through daylength extension lighting with metal halide lamps when PPF measured outside was below $387 \mu \mathrm{mol} \cdot \mathrm{m}^{-2} \cdot \mathrm{s}^{-1}$ from 1000 to $2400 \mathrm{HR}$ to maintain the poinsettia stock plants in a vegetative state for cutting production. A peatbased growing medium (Fafard 3B; Conrad Fafard, Agawam, MA) was used for all experiments. A constant liquid fertigation schedule was used with $\quad 15 \mathrm{~N}-2.2 \mathrm{P}-12.5 \mathrm{~K}-5 \mathrm{Ca}-2 \mathrm{Mg}$ water-soluble fertilizer (Peter's Excel; ICL Specialty Fertilizers, Dublin, $\mathrm{OH}$ ) to provide $200 \mathrm{mg} \cdot \mathrm{L}^{-1} \mathrm{~N}$ and 66 $\mathrm{mg} \cdot \mathrm{L}^{-1} \mathrm{Ca}$ at each irrigation.

Treatment application. Six treatments comprising different concentrations of either Ca or SA were arranged as a completely randomized design with six individual stock plants (replicates) per treatment. A Ca-EDTA [Ca disodium EDTA ( $\mathrm{CaNa}_{2} \mathrm{EDTA}$ ), 9\% Ca chelate (Sequestar; Blackmore Co., Belleville, MI)] solution was prepared with deionized water to provide $C a$ at $0,40,80$, or $160 \mathrm{mg} \cdot \mathrm{L}^{-1}$. An SA [2-hydroxybenzoic acid, >99.0\% (MP Biomedicals, Solon, OH)] solution was prepared with 150 or 300 $\mathrm{mg} \cdot \mathrm{L}^{-1} \mathrm{SA}$ in deionized water after being dissolved in $10 \mathrm{~mL}$ of heated water $\left(60^{\circ} \mathrm{C}\right)$. A non-ionic surfactant (CapSil; Aquatrols, Paulsboro, NJ) was added to each solution at a concentration of $0.4 \mathrm{~mL} \cdot \mathrm{L}^{-1}$ to improve leaf contact. All treatments were applied weekly to poinsettia stock plants as a foliar spray to glisten the foliage, between 0800 and $1100 \mathrm{HR}$ at an application rate of $200 \mathrm{~mL} \cdot \mathrm{m}^{-2}$ bench space. Shoot tip cuttings $(5-\mathrm{cm}$ stem length with four to five leaves) were harvested weekly from the stock plants to provide cuttings for analysis and to stimulate further shoot formation.

Three different evaluations were performed to determine the treatment effects on plant tissues. The evaluations included leaf texture analysis, leaf nutrient analysis, and moisture loss. Sampling for each analysis method started 6 weeks following initiation of treatment applications and continued as required for each analysis described in the sections to follow.

TEXTURE ANALYSIS FOR MECHANICAL PROPERTIES. A $3-\mathrm{cm}^{-}$ long leaf that developed on each axillary shoot following pinching was tagged on the same day across all stock plants. Each stock plant had one leaf marked on each of six shoots. When those tagged leaves reached a mature size, they were harvested in the morning (0800-1000 HR), wrapped in moist paper towel, placed in a sealed polyethylene bag (17.7 $\times$ $19.5 \mathrm{~cm})$, and placed in a $5{ }^{\circ} \mathrm{C}$ room until the start of measurement the following day. Texture analysis was performed within 24 to $32 \mathrm{~h}$ from leaf removal, and there were six leaves per replicate.

The texture analysis procedure involved forcing a probe of a known cross-sectional area through a leaf causing the leaf to fracture (GutiérrezRodríguez et al., 2013). A texture analyzer (TA-XT Plus; Stable Microsystems, Godalming, UK) was used with a TA-1085 small film extension fixture (Stable Microsystems) with a 10mm-diameter opening $\left(78.5 \mathrm{~mm}^{2}\right)$ to hold the leaf and $6.35-\mathrm{mm}$-diameter ball probe (rounded end) to penetrate the leaf. The test specifications were a pre-test speed of $2 \mathrm{~mm} \cdot \mathrm{s}^{-1}$, test speed of $1 \mathrm{~mm} \cdot \mathrm{s}^{-1}$, and post-test speed of 10 $\mathrm{mm} \cdot \mathrm{s}^{-1}$. The probe moved a standard distance of $8 \mathrm{~mm}$. Each leaf was placed between two metal plates and clamped to keep the leaf flat. Leaves were cut at the midrib immediately before the measurement and the test was performed on both halves of each leaf with the probe penetrating from the adaxial side, avoiding conspicuous veins. A forcedisplacement graph was generated for each test. From this graph, the peak (maximum) force to puncture the leaf and area under the force displacement curve, which also is referred to as the work-of-penetration, were identified for each leaf analyzed.

LEAF NUTRIENT ANALYSIS. The newest, fully developed leaf on each of six shoots per stock plant was collected between 0800 and 1000 $\mathrm{HR}$, washed with deionized water, air dried at $20{ }^{\circ} \mathrm{C}$ for $48 \mathrm{~h}$, and placed in an oven at $60{ }^{\circ} \mathrm{C}$ until the weight was constant. The dried samples were ground to a fine powder for analysis of macro and micronutrients of leaves (Nelson, 1988) using inductively coupled plasma optical emission spectrometry (iCAP 6300; Thermo Fisher Scientific, Waltham, MA) and a carbon nitrogen analyzer (Vario MICRO cube CHNS; Elementar, Mt. Laurel, NJ) at the U.S. Department of Agriculture, Agricultural Research Service laboratory in Toledo, $\mathrm{OH}$.

WATER Loss. Six shoot tip cuttings per stock plant were harvested for postharvest simulation. Three cuttings were placed in one zip-sealed polyethylene bag $(17.7 \times 19.5 \mathrm{~cm})$ with 15 round holes $\left(0.65 \mathrm{~mm} \mathrm{di}^{-}\right.$ ameter) on each side and two bags per replicate/plant; hence, there were 12 bags per treatment. A simulated postharvest environment was provided by placing the bags of cuttings in dark storage at $10{ }^{\circ} \mathrm{C}[70 \%$ to $80 \%$ relative humidity $(\mathrm{RH})]$ for $48 \mathrm{~h}$ followed by $20{ }^{\circ} \mathrm{C}$ for $24 \mathrm{~h}(70 \%$ to $80 \% \mathrm{RH})$ in a growth room with temperature and humidity sensors connected to a data logger.

The fresh weight (FW) of six cuttings was recorded at harvest, or Day $0\left(\mathrm{FW}_{\mathrm{D} 0}\right)$, and again after $3 \mathrm{~d}$ simulated postharvest storage $\left(\mathrm{FW}_{\mathrm{D} 3}\right)$. Then cuttings were oven-dried at $60^{\circ} \mathrm{C}$ until the weight was constant and dry weight (DW) was recorded. Water content of a cutting at harvest was determined by subtracting DW from $\mathrm{FW}_{\mathrm{D} 0}$. Moisture 
loss was calculated by subtracting $\mathrm{FW}_{\mathrm{D} 3}$ from $\mathrm{FW}_{\mathrm{D} 0}$. Relative moisture loss from cuttings was calculated as a percentage of moisture loss from the water content at harvest, as it gives an indication of transpiration rate during the postharvest storage as expressed in Eq. [1]. No additional moisture was provided within the bag during postharvest storage.

$$
\begin{aligned}
& \text { Relative moisture loss }= \\
& \frac{F W_{D 3}-F W_{D O}}{F W_{D O}-D W} \times 100
\end{aligned}
$$

Data ANAlysis. Data were analyzed using analysis of variance in JMP Pro 10 (SAS Institute, Cary, NC). Trend lines were plotted using a three-parameter, exponential growth nonlinear equation for the leaf mechanical properties and nutrient analysis data, and a two-parameter, exponential decay nonlinear equation for the moisture loss data.

\section{Results}

LEAF MECHANICAL PROPERTIES. Peak force increased by $26 \%$ greater $(P=0.01)$ as $\mathrm{Ca}$ application rate increased from 0 to $80 \mathrm{mg} \cdot \mathrm{L}^{-1}$, whereas no additional increase was observed at $160 \mathrm{mg} \cdot \mathrm{L}^{-1} \mathrm{Ca}$. (Fig. 1A). Work-of-penetration increased by $29 \%(P=0.05)$ as $\mathrm{Ca}$ application rate increased from 0 to $160 \mathrm{mg} \cdot \mathrm{L}^{-1}$ (Fig. 1B). No change in leaf mechanical properties were observed from the SA applications (data not shown).

LEAF NUTRIENT CONCENTRATION. Calcium concentration in the poinsettia leaves increased by $27 \%$ with increased application of Ca from 0 to $160 \mathrm{mg} \cdot \mathrm{L}^{-1}[P<0.0001$ (Fig. $2 \mathrm{~A})]$. The other macronutrients measured in the leaf tissue were not different among the $\mathrm{Ca}$ treatments $(P>0.05)$. Elemental analysis of the Ca-EDTA solution with surfactant indicated the presence of aluminum, boron $(\mathrm{B}), \mathrm{Ca}$, copper $(\mathrm{Cu})$, iron $(\mathrm{Fe})$, potassium, manganese, molybdinum, phosphorus, and sulfur; therefore, the Ca-EDTA applications resulted in increases in several of the micronutrients (data not shown). For example, B increased by $59 \%(P<$ $0.007), \mathrm{Cu}$ by $68 \%(P<0.0001), \mathrm{Fe}$ by $38 \%(P<0.05)$, and zinc $(\mathrm{Zn})$ by $41 \%(P<0.0001)$ with application of Ca-EDTA at $160 \mathrm{mg} \cdot \mathrm{L}^{-1} \mathrm{Ca}$ (Fig. 2B-F). All nutrients, except for $\mathrm{Cu}$, were within the acceptable range for poinsettia leaf tissue (Ecke et al., 2004). Variation of macro- or micronutrient concentration was not evident following application of SA (data not shown). Phytotoxicity symptoms in the form of yellowing and necrotic patches near the leaf margins were observed following applications of $160 \mathrm{mg} \cdot \mathrm{L}^{-1} \mathrm{Ca}$ and $300 \mathrm{mg} \cdot \mathrm{L}^{-1} \mathrm{SA}$.

WATER Loss. Cutting FW and DW at harvest was not different among treatments, with an average of $28.8 \pm 3.4 \mathrm{~g}$ and $3.9 \pm 0.6 \mathrm{~g}$, respectively. Initial relative water content was $86.6 \% \pm 1.1 \%$. The $\mathrm{Ca}$ and SA spray treatments reduced moisture loss during storage compared with the control; however, no differences were observed amongst the various rates of Ca or SA (Fig. 3).

\section{Discussion}

Calcium applied to poinsettias at or above $80 \mathrm{mg} \cdot \mathrm{L}^{-1}$ in the form of $\mathrm{Ca}$ EDTA can improve leaf mechanical strength. As reported in our previous studies, when $\mathrm{CaCl}_{2}$ was used as the Ca source, the effect on mechanical strength was evident at $400 \mathrm{mg} \cdot \mathrm{L}^{-1}$ Ca with a $10 \%$ increase in work-ofpenetration (Samarakoon et al., 2017). Since the work-of-penetration increased by $24 \%$ when Ca-EDTA was applied, it could be considered more effective in strengthening the leaves than $\mathrm{CaCl}_{2}$. The mode of action of $\mathrm{Ca}$ was hypothesized to be via increased lignin and cellulose content in cell walls (Conn et al., 2011) and/ or strengthening the middle lamella (Hongo et al., 2012). However, the relative increase of $\mathrm{Ca}$ in our previous studies with $\mathrm{CaCl}_{2}$ was $37 \%$ (Samarakoon et al., 2017) as compared with $27 \%$ in the current study with CA-EDTA. A chelating agent can influence $\mathrm{Ca}$ uptake as well as other micronutrients ( $\mathrm{B}, \mathrm{Cu}, \mathrm{Fe}, \mathrm{Zn})$; therefore, it is possible that the increased concentrations of other nutrients may also have contributed to increased leaf mechanical strength.

Phytotoxicity symptoms following application of $\mathrm{Ca}$-EDTA have been reported in hydroponic tulip production (Nelson and Niedziela, 1998). The phytotoxicity symptoms observed on applications of $160 \mathrm{mg} \cdot \mathrm{L}^{-1} \mathrm{Ca}$ could be due to nutrient imbalances resulting from the treatment applications or leaf burn due to high salt concentration. Our results suggest that $80 \mathrm{mg} \cdot \mathrm{L}^{-1} \mathrm{Ca}$

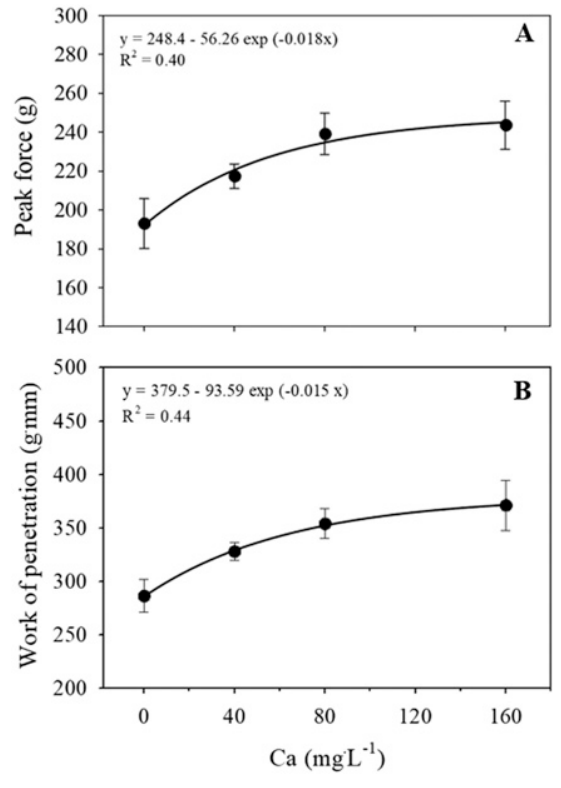

Fig. 1. Leaf mechanical strength as indicated by peak force (A), and work-of-penetration (B) for 'Prestige Red' poinsettia leaves. Leaves were sampled from cuttings following weekly foliar spray applications of chelated calcium (Ca-EDTA) at rates of 0 to $160 \mathrm{mg} \cdot \mathrm{L}^{-1} \mathrm{Ca}$ to stock plants during cutting development $(n=6)$; $1 \mathrm{mg} \cdot \mathrm{L}^{-1}=1 \mathrm{ppm}, 1 \mathrm{~g}=0.0353 \mathrm{oz}$, $1 \mathrm{~g} \cdot \mathrm{mm}=0.0014 \mathrm{oz}$-inch.

from Ca-EDTA would be sufficient to increase mechanical strength without substantial risk of phytotoxicity. Foliar $\mathrm{Ca}$ application has been a common technique to control bract edge burn and leaf edge necrosis since the 1990s (Ecke et al., 2004). As evidenced by the increased Ca concentration in the tissues of the Ca-EDTA-treated leaves, Ca-EDTA can be useful for overcoming Ca deficiencies and their associated physiological disorders observed in poinsettia. Based on preliminary investigations, application of $\mathrm{Ca}$ to stock plants was not inhibitory to rooting initiation and development during propagation.

Both $\mathrm{Ca}$ and SA reduced the moisture loss from cuttings as compared with control. Reduction of evapotranspiration with application of $\mathrm{CaCl}_{2}$ was observed in big bend bluebonnet [ $\mathrm{Lupi}$ nus harvardii (Picchioni et al., 2001)], and improved moisture retention and turgor was achieved with application of $\mathrm{Ca}$ in lettuce [Lactuca sativa (MartinDiana et al., 2006)]. Treatment of common bean (Phaseolus vulgaris) leaves with SA reduced transpiration rates (Larque-Saavedra, 1979), via 


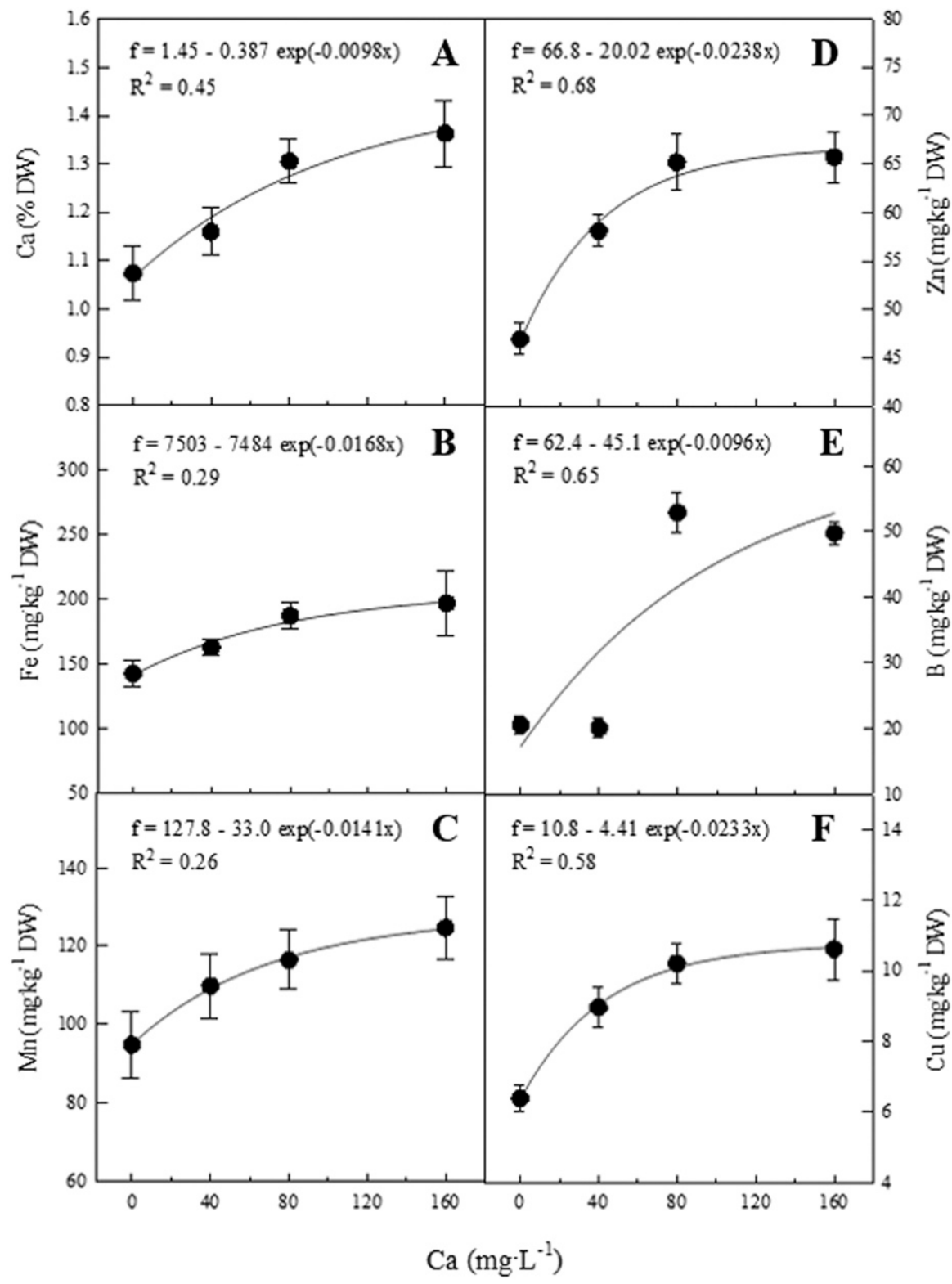

Fig. 2. Concentration of calcium [Ca (A)], iron [ $\mathrm{Fe}(\mathrm{B})]$, manganese $[\mathrm{Mn}(\mathrm{C})]$, $\operatorname{zinc}[\mathrm{Zn}(\mathrm{D})]$, boron $[\mathrm{B}(\mathrm{E})]$, and copper $[\mathrm{Cu}(\mathrm{F})]$ measured in 'Prestige Red' poinsettia leaves following weekly foliar applications of chelated $\mathrm{Ca}(\mathrm{Ca}-\mathrm{EDTA})$ at rates of 0 to $160 \mathrm{mg} \cdot \mathrm{L}^{-1} \mathrm{Ca}(\mathrm{n}=6) ; 1 \mathrm{mg} \cdot \mathrm{L}^{-1}=1 \mathrm{ppm}, 1 \mathrm{mg} \cdot \mathrm{kg}^{-1}=1 \mathrm{ppm}, 1 \mathrm{~g}=$ 0.0353 oz.

increased abscisic acid synthesis (Bandurska, 2005). Increased postharvest life of cut roses via regulation of water balance following application of SA was previously reported (Alaey et al., 2011). On the basis of the current study and these other reports, both Ca-EDTA and SA reduce moisture loss during postharvest storage and shipping.

In conclusion, foliar applications of Ca-EDTA can be used to increase cutting quality and postharvest performance. Use of foliar sprays is relatively convenient in commercial facilities

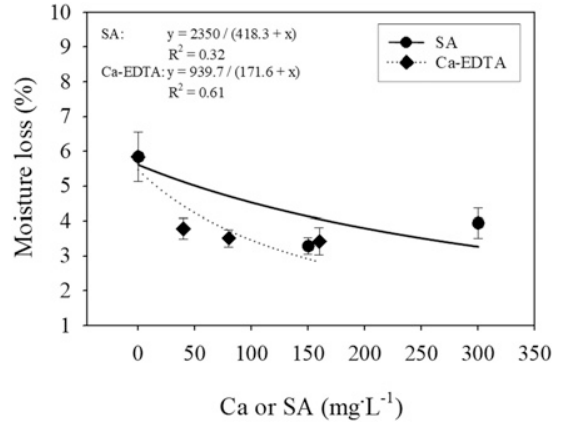

Fig. 3. Moisture loss percentage during postharvest simulation of 'Prestige Red' poinsettia cuttings following weekly foliar spray applications of chelated calcium (CaEDTA) at rates of 0 to $160 \mathrm{mg} \cdot \mathrm{L}^{-1} \mathrm{Ca}$ or 0 to $300 \mathrm{mg} \cdot \mathrm{L}^{-1}$ salicylic acid (SA) to stock plants $(\mathrm{n}=6) ; 1 \mathrm{mg} \cdot \mathrm{L}^{-1}=1$ ppm.

\section{Literature cited}

Alaey, M., M. Babalar, R. Naderi, and M. Kafi. 2011. Effect of pre-and postharvest salicylic acid treatment on physio-chemical attributes in relation to vase-life of rose cut flowers. Postharvest Biol. Technol. 61:91-94.

Alarcón, A.L., R. Madrid, F. Romojaro, and E. Molina. 1998. Calcium forms in leaves of muskmelon plants grown with different calcium compounds. J. Plant Nutr. 21:1897-1912.

Bandurska, H. 2005. The effect of salicylic acid on barley response to water deficit. Acta Physiol. Plant. 27:379-386.

Champa, W.H., M. Gill, B. Mahajan, and N. Arora. 2014. Preharvest salicylic acid treatments to improve quality and postharvest life of table grapes (Vitis vinifera L.) cv. Flame Seedless. J. Food Sci. Technol. 52:3607-3616.

Conn, S.J., M. Gilliham, A. Athman, A. W. Schreiber, U. Baumann, I. Moller, N. H. Cheng, M.A. Stancombe, K.D. Hirschi, A.A. Webb, R. Burton, B.N. Kaiser, S.D. Tyerman, and R.A. Leigh. 2011. Cellspecific vacuolar calcium storage mediated by CAXI regulates apoplastic calcium concentration, gas exchange, and plant productivity in Arabidopsis. Plant Cell 23:240-257.

Ecke, P., III., J. Faust, A. Higgins, and J. Williams. 2004. The Ecke poinsettia manual. Ball Publ., West Chicago, IL.

Gutiérrez-Rodríguez, E., H.J. Lieth, J.A. Jernstedt, J.M. Labavitch, T.V. Suslow, and M.I. Cantwell. 2013. Texture, composition and anatomy of spinach leaves in relation to nitrogen fertilization. J. Sci. Food Agr. 93:227-237. 


\section{Research Reports}

Hayat, Q., S. Hayat, M. Irfan, and A. Ahmad. 2010. Effect of exogenous salicylic acid under changing environment: A review. Environ. Expt. Bot. 68:14-25.

Hongo, S., K. Sato, R. Yokoyama, and K. Nishitani. 2012. Demethylesterification of the primary wall by pectin methylesterase provides mechanical support to the Arabidopsis stem. Plant Cell 24:26242634.

Larque-Saavedra, A. 1979. Stomatal closure in response to acetylsalicylic acid treatment. Z. Pflanzenphysiol. 93:371375 .

Martin-Diana, A.B., D. Rico, J. Frias, G. Henehan, J. Mulcahy, J. Barat, and C. Barry-Ryan. 2006. Effect of calcium lactate and heat-shock on texture in fresh-cut lettuce during storage. J. Food Eng. 77:1069-1077.
Nelson, M.R. 1988. Index to EPA methods. EPA Circ. 901/3-88-01. U.S Environ. Protection Agency, Washington, DC.

Nelson, P. and C. Niedziela. 1998. Effects of calcium source and temperature regime on calcium deficiency during hydroponic forcing of tulip. Scientia Hort. 73:137-150.

Picchioni, G., M. Valenzuela-Vazquez, and S. Armenta-Sanchez. 2001. Calciumactivated root growth and mineral nutrient accumulation of Lupinus havardii: Ecophysiological and horticultural significance. J. Amer. Soc. Hort. Sci. 126:631637.

Rivas-San Vicente, M. and J. Plasencia. 2011. Salicylic acid beyond defence: Its role in plant growth and development. J. Expt. Bot. 62:3321-3338.
Samarakoon, U.C., J.E. Faust, and J.M. Dole. 2017. Quantifying the effects of foliar-applied calcium chloride and its contribution to postharvest durability of unrooted cuttings. HortScience 52:17901795.

Shafiee, M., T. Taghavi, and M. Babalar. 2010. Addition of salicylic acid to nutrient solution combined with postharvest treatments (hot water, salicylic acid, and calcium dipping) improved postharvest fruit quality of strawberry. Scientia Hort. 124:40-45.

Tang, S., W. Shi, H. Wang, and A. Luo. 2007. Effect of calcium on cyclamen pedicel elongation. J. Plant Nutr. Soil Sci. 170:664-668. 